Вип. 1, 2019

УДК 621.316.925

А. С. Куцик

Національний університет “Львівська політехніка", кафедра електроприводу і комп’ютеризованих електромеханічних систем, andrii.s.kutsyk@1pnu.ua,

О. Г. Плахтина

Національний університет “Львівська політехніка", кафедра електроприводу і комп'ютеризованих електромеханічних систем, omelian.g.plakhtyna@lpnu.ua

\title{
МАТЕМАТИЧНЕ МОДЕЛЮВАННЯ В РЕАЛЬНОМУ ЧАСІ АСИНХРОННОГО ГЕНЕРАТОРА 3 ІНВЕРТОРОМ НАПРУГИ В КОЛІ РОТОРА
}

https://doi.org/10.23939/sepes2019.01.025

(C) Куциик А. С., Плахтина О. Г., 2019

Описано математичну модель електромеханічної системи із асинхронним генератором із регулюванням струму ротора перетворювачем частоти 3 автономним інвертором напруги, керованим регуляторами струму.

Асинхронні генератори завдяки їх простоті доволі широко використовують у вітроенергетичних установках. Регулювання струмів ротора за допомогою перетворювача частоти дає змогу регулювати швидкість та коефіціснт потужності в колі статора. Потужність перетворювача частоти визначається діапазоном зміни ковзання i може становити 25-30 \% сумарної потужності генератора.

Синтез відповідної системи керування вимагає розроблення математичної моделі, яка повинна враховувати нелінійність магнітних зв'язків у асинхронній машині та взаємні впливи між компонентами системи. Посднання реальної системи керування 3 математичною моделлю силової схеми системи генерування електроенергії за технологією "hardware-in-the-loоp", яка працює у реальному часі, дає змогу провести випробування та налаштування системи керування.

Для створення математичної моделі застосовано оригінальний авторський метод середніх напруг на кроці числового інтегрування для математичного моделювання електричних кіл. Застосування цього методу забезпечус високу швидкодію та числову стійкість і створює умови для неперервної роботи моделі в режимі реального часу в посднанні із фізичними об' сктами (наприклад, із фізичним контролером). Це дає змогу використати їі для синтезу та тестування систем керування асинхронним генератором.

Реалізована в моделі система векторного керування забезпечус регулювання швидкості обертання генератора та реактивної потужності в колі статора і створює умови для використання зазначеної системи, наприклад, для вітроенергетичних установок.

Ключові слова: асинхронний генератор; real-time модель; математичне моделювання; векторне керування. 


\section{А. С. Куцик, О. Г. Плахтина}

\section{Постановка проблеми}

Асинхронні генератори (АГ) широко застосовують у вітроенергетиці, що зумовлено відомими перевагами асинхронних машин, зокрема простотою, дешевизною і невибагливістю в обслуговуванні. У вітроенергетичних установках більшої потужності часто використовують асинхронні машини із фазним ротором у схемах із подвійним живленням, які дають змогу регулювати реактивну потужність та швидкість обертання. Синтез систем керування такими агрегатами потребує застосування відповідних математичних моделей. Перспективною є технологія синтезу та діагностування систем керування із використанням real-time моделей силової частини, які функціонують із реальною системою керування. До таких моделей ставлять підвищені вимоги щодо швидкодії та стійкості обчислень, що повинно гарантувати їх тривалу безперервну роботу в реальному масштабі часу. В статті розроблено таку модель асинхронного генератора 3 регулюванням струму ротора за допомогою інвертора напруги.

\section{Аналіз останніх досліджень}

Асинхронні машини із фазним ротором часто використовують у вітроенергетичних установках середньої та великої потужності, що зумовлено відомими конструктивними перевагами асинхронних машин [1-5]. Використання асинхронних машин із подвійним живленням 3 регулюванням струмів ротора за допомогою перетворювача частоти в колі ротора дає змогу також регулювати швидкість обертання генератора в широкому діапазоні, що необхідно для забезпечення максимального відбору енергії вітру. Потужність перетворювача частоти визначається діапазоном зміни ковзання i, за даними [1], для забезпечення завдань регулювання може становити 25-30 \% сумарної потужності генератора. Істотними перевагами асинхронних генераторів у схемах із подвійним живленням $\epsilon$ можливість регулювання реактивної потужності в статорі. Для керування асинхронним генератором у таких системах використовують переважно алгоритми векторного керування [1-3]. Синтез таких систем керування потребує інформації про поведінку об'єкта в різних режимах роботи. Отримати таку інформацію можливо за допомогою відповідних математичних моделей, що повинні враховувати нелінійність та взаємні впливи між компонентами системи.

Перспективним способом синтезу та діагностування розроблених систем керування $є$ використання технологій hardware-in-the-loop, які дають змогу поєднати реальну систему керування 3 цифровою моделлю об'єкта керування, яка функціонує у реальному часі [6-8]. В роботах $[6,8]$ описано, зокрема, спосіб тестування та налагодження систем регулювання збудження генераторів за допомогою цифрових real-time моделей системи генерування електроенергії. В роботі [2] подібні технології пропонують для синтезу систем керування асинхронним генератором у схемі подвійного живлення.

Для створення real-time цифрових моделей, придатних до тривалої неперервної роботи у взаємодії з фізичними об'єктами, необхідно використовувати методи математичного моделювання та числового інтегрування, що гарантують високу швидкодію розрахунку, числову стійкість та дають змогу врахувати нелінійність електромеханічної системи.

\section{Формування цілей статті}

Мета статті - розроблення та дослідження можливостей математичної та комп'ютерної realtime моделі асинхронного генератора у схемі подвійного живлення із контурами регулювання швидкості та реактивної потужності. Для створення такої моделі використано оригінальний авторський метод середніх напруг на кроці числового інтегрування, який, як показує досвід його використання, забезпечує високу точність розрахунку завдяки збільшеному кроку числового інтегрування, високу швидкодію розрахунку та числову стійкість.

\section{Виклад основного матеріалу}

Основні положення використаного методу середніх напруг на кроці числового інтегрування викладено в [9], де отримано таке алгебраїзоване рівняння, що описує електричну вітку в складі джерела ЕРС, опору, індуктивності та ємності 


$$
\begin{gathered}
U+E-u_{R 0}-u_{C 0}+\left(\frac{R}{m+1}+\frac{\Delta t}{C} \cdot \frac{2-(m+1)(m+2)}{2(m+1)(m+2)}+\frac{L_{0}}{\Delta t}\right) i_{0}- \\
-\sum_{k=1}^{m-1}\left(\frac{R \Delta t^{k}}{(k+1) !} \cdot \frac{m-k}{m+1}+\frac{\Delta t^{k+1}}{C(k+2) !} \cdot \frac{(m+1)(m+2)-(k+1)(k+2)}{(m+1)(m+2)}\right) \frac{d^{(k)} i_{0}}{d t^{(k)}}- \\
-\left(\frac{R}{m+1}+\frac{\Delta t}{C(m+1)(m+2)}+\frac{L_{1}}{\Delta t}\right) i_{1}=0
\end{gathered}
$$

де $m$ - порядок полінома, яким описано криву струму вітки на кроці числового інтегрування; $i_{0}, i_{1}-$ значення струму вітки на початку та в кінці кроку; $L_{0}, L_{1}-$ значення індуктивності вітки на початку та в кінці кроку; $u_{R 0}, u_{C 0}$ - значення напруги на опорі та конденсаторі на початку кроку; $U=\frac{1}{\Delta t} \int_{t_{0}}^{t_{0}+\Delta t} u d t, E=\frac{1}{\Delta t} \int_{t_{0}}^{t_{0}^{+}+\Delta t} e d t-$ середні на кроці числового інтегрування значення ЕРС вітки та прикладеної напруги.

Рівняння (1) є базовим для створення математичної моделі елементів електромеханічних систем. Модель системи загалом формують поєднанням моделей окремих елементів, поданих у формі багатополюсників. У цьому випадку модель системи генерування електроенергії 3 асинхронним генератором 3 інвертором в колі ротора формуватимемо із моделей асинхронної машини, трансформатора та керованих джерел живлення різного типу.

Розрахункову схему асинхронної машини з фазним ротором як 12-полюсника показано на рис. 1, де позначено: $\left(\varphi_{A 1}, \varphi_{B 1}, \varphi_{C 1}, \varphi_{a 1}, \varphi_{b 1}, \varphi_{c 1}\right)=\vec{\varphi}_{a m}^{I},\left(\varphi_{A 2}, \varphi_{B 2}, \varphi_{C 2}, \varphi_{a 2}, \varphi_{b 2}, \varphi_{c 2}\right)=\vec{\varphi}_{a m}^{I I}-$ вектори потенціалів полюсів, $\left(i_{A}, i_{B}, i_{C}, i_{a}, i_{b}, i_{c}\right)=\overrightarrow{\mathrm{i}}_{a m}-$ вектор струмів віток.

Рис. 1. Розрахункова схема асинхронної машини з фазним ротором

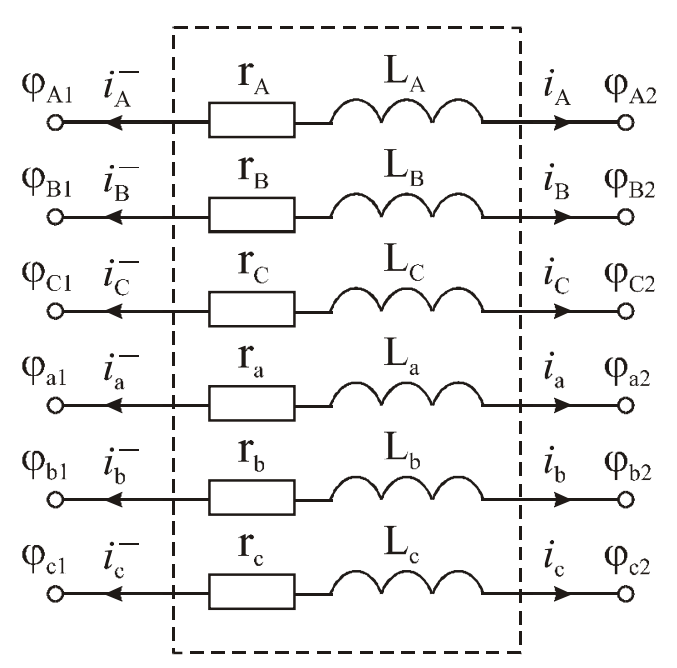

Застосувавши рівняння (1) для другого порядку $(m=2)$ до схеми асинхронної машини, отримуємо матричне рівняння:

$$
\overrightarrow{\mathrm{U}}-\overrightarrow{\mathrm{u}}_{R 0}+\frac{\breve{\mathrm{R}}_{a m}}{3} \overrightarrow{\mathrm{i}}_{a m 0}-\frac{\breve{\mathrm{R}}_{a m} \Delta t}{6} \frac{d \overrightarrow{\mathrm{i}}_{a m 0}}{d t}-\frac{\breve{\mathrm{R}}_{a m}}{3} \overrightarrow{\mathrm{i}}_{a m 1}-\frac{1}{\Delta t}\left(\vec{\psi}_{a m 1}-\vec{\psi}_{a m 0}\right)=0,
$$

де $U$ - вектор середніх на кроці числового інтегрування значень прикладених напруг:

$$
\overrightarrow{\mathrm{U}}=\frac{1}{\Delta t} \int_{t_{0}}^{t_{0}+\Delta t} \vec{\varphi}_{a m}^{I} d t-\frac{1}{\Delta t} \int_{t_{0}}^{t_{0}+\Delta t} \vec{\varphi}_{a m}^{I I} d t
$$

$\overrightarrow{\mathrm{u}}_{R 0}$ - вектор спадів напруг на активних опорах фаз обмоток статора і ротора на початку кроку інтегрування; $\breve{\mathrm{R}}_{a m}=\operatorname{diag}\left(R_{A}, R_{B}, R_{C}, R_{a}, R_{b}, R_{c}\right)$ - матриця активних опорів фаз обмоток статора $\mathrm{i}$ 


\section{А. С. Куцฺик, О. Г. Плахтина}

ротора; $\overrightarrow{\mathrm{i}}_{\text {am } 0}, \overrightarrow{\mathrm{i}}_{\text {am } 1}$ - вектори струмів обмоток статора $\mathrm{i}$ ротора на початку та в кінці кроку інтегрування; $\vec{\psi}_{a m 1}, \vec{\psi}_{a m 0}$ - вектори потокозчеплень обмоток статора і ротора на початку та в кінці кроку інтегрування (відношення різниці яких до кроку інтегрування визначає ЕРС, що індукуються в обмотках), які дорівнюють:

$$
\vec{\psi}_{a m 0}=\breve{\mathrm{L}}_{a m 0} \overrightarrow{\mathrm{i}}_{a m 0} \text { та } \vec{\psi}_{a m 1}=\breve{\mathrm{L}}_{a m 1} \overrightarrow{\mathrm{i}}_{a m 1}
$$

де $\breve{\mathrm{L}}_{a m 0}, \breve{\mathrm{L}}_{a m 1}$ - матриці власних та взаємних індуктивностей обмоток статора і ротора на початку та в кінці кроку інтегрування:

$$
\breve{\mathrm{L}}_{a m}=\left[\begin{array}{llllll}
\mathrm{L}_{\mathrm{AA}} & \mathrm{L}_{\mathrm{AB}} & \mathrm{L}_{\mathrm{AC}} & \mathrm{L}_{\mathrm{Aa}} & \mathrm{L}_{\mathrm{Ab}} & \mathrm{L}_{\mathrm{Ac}} \\
\mathrm{L}_{\mathrm{BA}} & \mathrm{L}_{\mathrm{BA}} & \mathrm{L}_{\mathrm{BC}} & \mathrm{L}_{\mathrm{Ba}} & \mathrm{L}_{\mathrm{Bb}} & \mathrm{L}_{\mathrm{Bc}} \\
\mathrm{L}_{\mathrm{CA}} & \mathrm{L}_{\mathrm{CB}} & \mathrm{L}_{\mathrm{CC}} & \mathrm{L}_{\mathrm{Ca}} & \mathrm{L}_{\mathrm{Cb}} & \mathrm{L}_{\mathrm{Cc}} \\
\mathrm{L}_{\mathrm{aA}} & \mathrm{L}_{\mathrm{aB}} & \mathrm{L}_{\mathrm{aC}} & \mathrm{L}_{\mathrm{aa}} & \mathrm{L}_{\mathrm{ab}} & \mathrm{L}_{\mathrm{ac}} \\
\mathrm{L}_{\mathrm{bA}} & \mathrm{L}_{\mathrm{bB}} & \mathrm{L}_{\mathrm{bC}} & \mathrm{L}_{\mathrm{ba}} & \mathrm{L}_{\mathrm{bb}} & \mathrm{L}_{\mathrm{bc}} \\
\mathrm{L}_{\mathrm{cA}} & \mathrm{L}_{\mathrm{cB}} & \mathrm{L}_{\mathrm{cC}} & \mathrm{L}_{\mathrm{ca}} & \mathrm{L}_{\mathrm{cb}} & \mathrm{L}_{\mathrm{cc}}
\end{array}\right] .
$$

Елементами матриці $\breve{\mathrm{L}}_{a m} \epsilon$ власні та взаємні індуктивності обмоток статора і ротора, які залежать від індуктивності намагнічування (залежить від струму намагнічування), індуктивностей розсіювання та кута повороту ротора $\gamma_{a m}$, який визначаємо з рівнянь

$$
\frac{d \gamma_{a m}}{d t}=z_{p} \omega_{r}, \quad \frac{d \omega_{r}}{d t}=\frac{M_{M}-M_{t}}{J}
$$

де $\omega_{r}$ - кутова швидкість обертання ротора; $z_{p}$ - кількість пар полюсів; $M_{M}$ - електромагнітний момент асинхронної машини; $M_{t}-$ зовнішній момент на валу (момент турбіни), який визначається як відношення заданої активної потужності генератора до заданої швидкості обертання $M_{t}=P_{3} / \omega_{3}, J$ - момент інерції.

Підставивши (4) і (3) в (2), з урахуванням $\overrightarrow{\mathrm{u}}_{R 0}=\breve{\mathrm{R}}_{\text {am }} \overrightarrow{\mathrm{i}}_{\text {ат } 0}$ отримаємо

$$
\frac{1}{\Delta t} \int_{t_{0}}^{t_{0}+\Delta t} \overrightarrow{\mathrm{v}}_{a m}^{I} d t-\frac{1}{\Delta t} \int_{t_{0}}^{t_{0}+\Delta t} \overrightarrow{\mathrm{v}}_{a m}^{I I} d t-\left(\frac{\breve{\mathrm{R}}_{a m}}{3}+\frac{\breve{\mathrm{L}}_{a m 1}}{\Delta t}\right) \overrightarrow{\mathrm{i}}_{a m 1}-\left(\frac{2 \breve{\mathrm{R}}_{a m}}{3}-\frac{\breve{\mathrm{L}}_{a m 0}}{\Delta t}\right) \overrightarrow{\mathrm{i}}_{a m 0}-\frac{\breve{\mathrm{R}}_{a m} \Delta t}{6} \frac{d \overrightarrow{\mathrm{i}}_{a m 0}}{d t}=0 .
$$

На основі рівняння (5) запишемо рівняння для асинхронної машини як багатополюсника:

$$
\vec{i}_{M}+\mathrm{G}_{M} \frac{1}{\Delta t} \int_{t_{0}}^{t_{0}+\Delta t} \vec{\varphi}_{M} d t+\vec{C}_{M}=0
$$

де $\vec{i}_{M}=\left[\begin{array}{c}-\vec{i}_{a m 1} \\ \vec{i}_{a m 1}\end{array}\right]-$ вектор струмів зовнішніх віток, $\vec{\varphi}_{M}=\left[\begin{array}{c}\vec{\varphi}_{a m}^{I} \\ \vec{\varphi}_{a m}^{I I}\end{array}\right]-$ вектор потенціалів зовнішніх полюсів: $\breve{\mathrm{G}}_{M}=\left[\begin{array}{cc}\breve{\mathrm{R}}_{M}^{-1} & -\breve{\mathrm{R}}_{M}^{-1} \\ -\breve{\mathrm{R}}_{M}^{-1} & \breve{\mathrm{R}}_{M}^{-1}\end{array}\right]$,

$$
\vec{C}_{M}=\left[\begin{array}{c}
-\breve{\mathrm{R}}_{M}^{-1}\left(\left(\frac{2 \breve{\mathrm{R}}_{a m}}{3}-\frac{\breve{\mathrm{L}}_{a m 0}}{\Delta t}\right) \vec{i}_{a m 0}+\frac{\breve{\mathrm{R}}_{a m} \Delta t}{6} \frac{d \vec{i}_{a m 0}}{d t}\right) \\
\breve{\mathrm{R}}_{M}^{-1}\left(\left(\frac{2 \breve{\mathrm{R}}_{a m}}{3}-\frac{\breve{\mathrm{L}}_{a m 0}}{\Delta t}\right) \vec{i}_{a m 0}+\frac{\breve{\mathrm{R}}_{a m} \Delta t}{6} \frac{d \vec{i}_{a m 0}}{d t}\right)
\end{array}\right], \breve{\mathrm{R}}_{M}=\frac{\breve{\mathrm{R}}_{a m}}{3}+\frac{\breve{\mathrm{L}}_{a m 1}}{\Delta t}
$$

Рівняння (6) є алгебраїзованим рівнянням для знаходження струмів обмоток статора і ротора в кінці кроку числового інтегрування $\overrightarrow{\mathrm{i}}_{M}$. Щоб знайти їх, необхідно знати вектор середніх на кроці числового інтегрування значень потенціалів полюсів $\frac{1}{\Delta t} \int_{t_{0}}^{t_{0}+\Delta t} \vec{\varphi}_{M} d t$, який згідно з [10] визначаємо як 


$$
\frac{1}{\Delta t} \int_{t_{0}}^{t_{0}+\Delta t} \vec{\varphi}_{e} d t=\breve{\Pi}^{T} \frac{1}{\Delta t} \int_{t_{0}}^{t_{0}+\Delta t} \vec{\varphi}_{c} d t
$$

де $\breve{П-~ м а т р и ц я ~ і н ц и д е н ц і і ̈, ~ я к а ~ з а д а є ~ с п о с і б ~ п і д ' є д н а н н я ~ п о л ю с і в ~ е л е м е н т а-б а г а т о п о л ю с н и к а ~ д о ~}$ незалежних вузлів системи; $\frac{1}{\Delta t} \int_{t_{0}}^{t_{0}+\Delta t} \vec{\varphi}_{c} d t-$ вектор середніх на кроці числового інтегрування значень потенціалів незалежних вузлів системи (точок з'єднання між собою зовнішніх віток елементівбагатополюсників), який визначаємо з рівняння:

$$
\breve{\mathrm{G}}_{s c} \frac{1}{\Delta t} \int_{t_{0}}^{t_{0}+\Delta t} \vec{\varphi}_{c} d t+\vec{C}_{s c}=0 .
$$

Рівняння (8) отримано застосуванням першого закону Кірхгофа до розрахункової схеми системи, а його коефіцієнти визначають на основі коефіцієнтів рівняння виду (6) всіх елементів, що входять до складу системи, та їх матриць інциденцій за формулами:

$$
\breve{\mathrm{G}}_{s c}=\sum_{j=1}^{L} \breve{\Pi}_{j} \breve{\mathrm{G}}_{j} \breve{\Pi}_{j}^{T}, \vec{C}_{s c}=\sum_{j=1}^{L} \breve{\Pi}_{j} \vec{C}_{j},
$$

де $L$ - кількість елементів у системі.

Як видно з рівнянь (5) і (6), для знаходження струмів обмоток необхідне значення похідних струмів на початку кроку інтегрування $\frac{d \vec{i}_{a m 0}}{d t}$. Їх знаходимо за принципами, описаними в [10].

За аналогічними принципами створено математичні моделі трансформатора як 12-полюсника (розрахункова схема аналогічна до розрахункової схеми асинхронної машини) та трифазних джерел живлення з ЕРС, активним опором та індуктивністю.

Розрахункову схему електромеханічної системи із асинхронним генератором у схемі 3 живленням кола ротора показано на рис. 2. До складу цієї системи входять такі елементи: багатополюсники: асинхронна машина (AM), двообмотковий трансформатор (Тр), мережа та джерела живлення ДС1, ДС2.

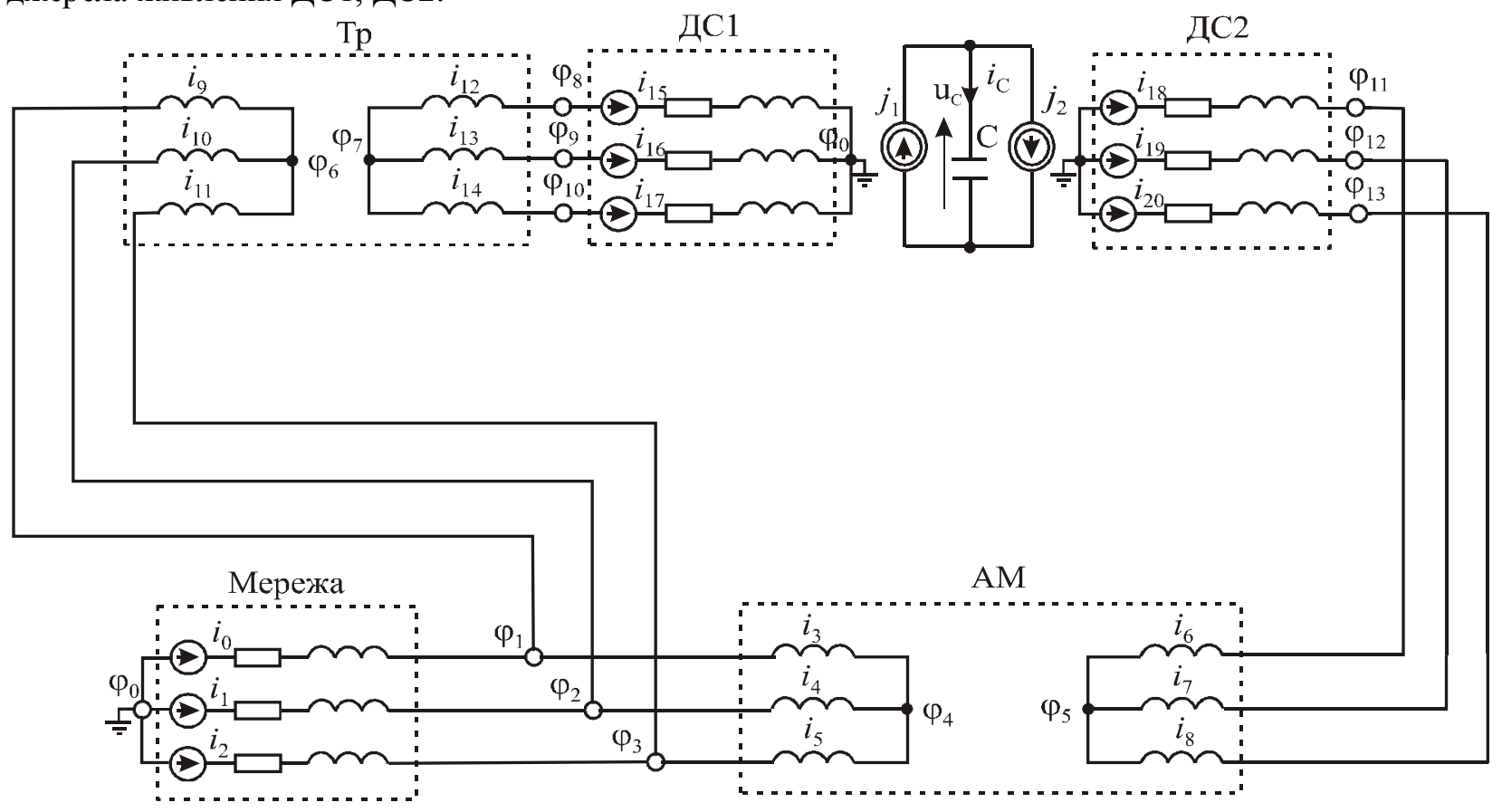

Рис. 2. Розрахункова схема

електромеханічної системи з асинхронним генератором у схемі з живленням кола ротора 


\section{А. С. Куцик, О. Г. Плахтина}

Математичну модель перетворювача частоти реалізовано за допомогою двох джерел живлення: ДС1 - вхідне коло, ДС2 - вихідне коло за принципами, описаними в [5]. ЕРС джерела живлення ДС2 визначається гістерезисними регуляторами струму ротора асинхронного генератора за сигналами системи керування і дорівнює $\pm U c$, що відповідає реальним напругам, які формуються на виході інвертора напруги, керованого гістерезисними регуляторами струму. ЕРС джерела живлення ДС1, що моделює вхідне коло перетворювача частоти, визначається регуляторами струму 3 умови формування такого значення вхідного струму перетворювача частоти, яке відповідає розрахованій потужності в колі ротора асинхронного генератора $P_{r}$ (якщо припустити, що немає втрат у ланці постійного струму) $I_{g}=\frac{2 P_{r}}{3 U_{r}}$, де $U_{r}$ - амплітудне значення фазної напруги на вході перетворювача частоти.

Напругу конденсатора визначимо з рівняння

$$
\frac{d U_{C}}{d t}=\frac{I_{r}-I_{g}}{C}
$$

де $I_{r}=J_{2}, I_{g}=J_{1}$ - амплітуди струму ротора та вхідного струму перетворювача частоти.

За такого способу моделювання перетворювача частоти, порівняно 3 моделюванням на рівні окремих вентилів з урахуванням їх комутації, немає необхідності знаходити моменти відкривання та закривання вентилів, що суттєво сповільнює розрахунок та ускладнює роботу моделі в реальному масштабі часу.

Структурну схему системи векторного керування асинхронним генератором з орієнтацією за потокозчепленням ротора показано на рис. 3. Система керування містить регулятор швидкості, вихідний сигнал якого задає струм ротора по осі $q$. Сигнал завдання струму ротора по осі $d$ визначається 3 умови забезпечення заданого значення реактивної потужності в статорі $Q_{3}$ (задається у відносних одиницях відносно номінального значення, що відповідає номінальному значенню струму намагнічення $\left.I_{m n}\right)$. Приймаємо допущення про лінійність кривої намагнічення. Неточності регулювання реактивної потужності, спричинені таким допущенням, можна усунути відповідним корегуванням сигналу завдання $Q^{*}$. На основі сигналів завдання струмів ротора в координатах $d q$ визначають сигнали завдання фазних струмів ротора, які відпрацьовуються відповідними гістерезисними регуляторами струму, вихідні сигнали яких визначають ЕРС джерела живлення ДС2.

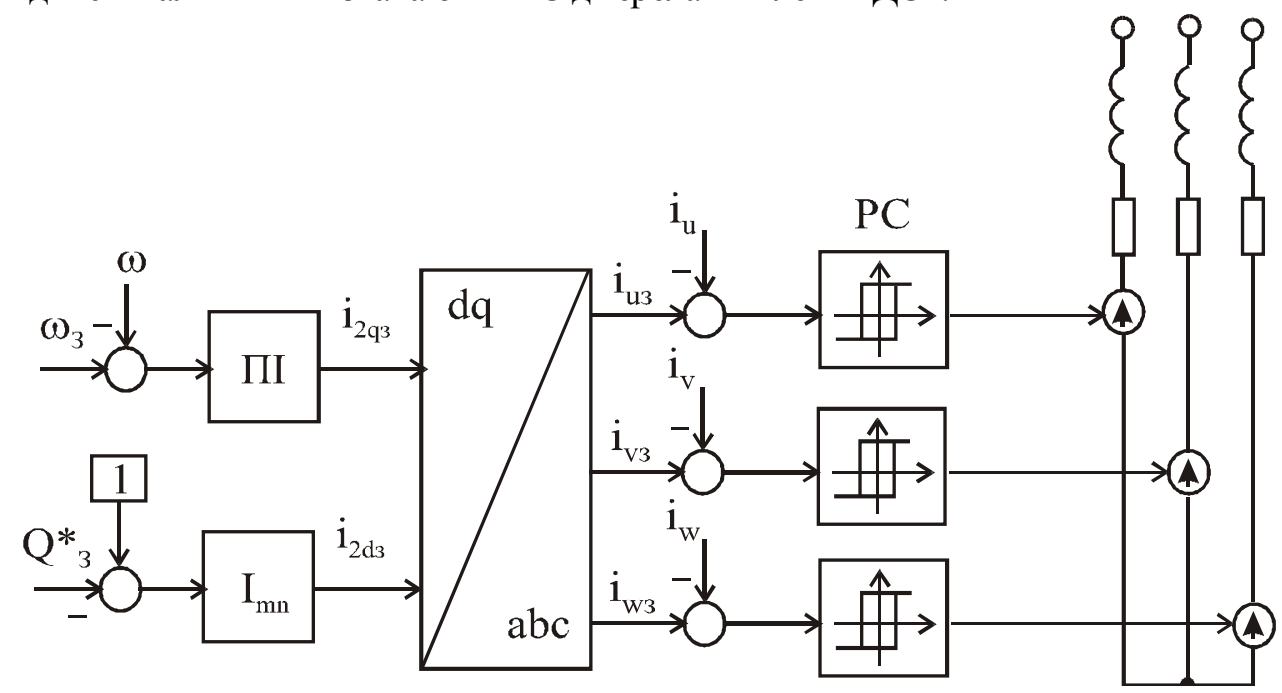

Рис. 3. Структурна схема системи керування

Для забезпечення роботи моделі в реальному масштабі необхідне виконання умови рівності розрахункового часу моделі та реального часу впродовж усього періоду функціонування моделі. Для 
цього використано процедуру автоматичної синхронізації розрахункового часу моделі з реальним часом відповідною зміною кроку числового інтегрування, описану в [11]. Для іiі реалізації необхідне точне вимірювання реального часу, що забезпечено в комп'ютерній моделі за допомогою функції QueryPerformanceCounter. Зазначимо, що отриманий крок числового інтегрування не повинен бути більшим за половину періоду комутації вентилів, тобто половину мінімального періоду перемикання вихідного сигналу гістерезисного регулятора струму. Якщо остання вимога не задовольняється, то необхідно вибирати для реалізації моделі комп'ютер із вищою швидкодією обчислень або зменшувати частоту перемикання гістерезисних регуляторів, збільшуючи ширину гістерезису.

\section{Результати досліджень}

Дослідження проводили для асинхронної машини із такими номінальними даними: напруга $U_{n}=690 \mathrm{~B}$, потужність $P_{n}=1800$ кВт, струм статора $I_{n}=1722 \mathrm{~A}$, струм ротора $I_{2 n}=587 \mathrm{~A}, \cos \varphi=0,87$.

Для оцінювання ефективності розробленої моделі та системи керування асинхронним генератором та їх придатності до практичного використання досліджено режими роботи асинхронного генератора із постійною потужністю на валу (потужністю турбіни) і з регулюванням швидкості обертання та забезпеченням одиничного коефіцієнта потужності в колі статора. Дослідження виконано для таких режимів:

Діапазон часу від 0 до 2 c - намагнічення асинхронної машини під'єднанням обмотки статора до мережі, обмотка ротора розімкнута (в цьому випадку статор споживає лише реактивну потужність (рис. 9).

Діапазон часу від 2 до 8 с - вмикання ротора 3 системою керування, яка забезпечує одиничний коефіцієнт потужності в колі статора (у такому разі струм намагнічення є складовою струму ротора), розгін асинхронної машини в режимі двигуна до синхронної швидкості обертання (157 $\mathrm{c}^{-1}$, рис. 8$)$ за дії рушійного моменту з боку турбіни, що сприяє розганянню (рис. 5, додатний знак моменту турбіни на рис. 5 відповідає гальмівному характеру).

Діапазон часу від 8 до 16 с - гальмування до швидкості, нижчої від синхронної $\left(127 \mathrm{c}^{-1}\right.$, рис. 8); у такому разі електромагнітний момент асинхронного генератора зростає у від'ємну сторону (гальмівний характер), а його максимальне значення обмежується регулятором 3 умови обмеження максимального значення струму (2500 А); рушійний момент турбіни зі зменшенням швидкості зростає з огляду на допущення про сталу активну потужність на валу генератора.

Діапазон часу від 16 до $20 \mathrm{c}$ - розгін генератора до швидкості, вищої від синхронної (187 $\mathrm{c}^{-1}$, рис. 8); в перехідному процесі асинхронна машина переходить в режим двигуна і споживає активну потужність 3 мережі, а момент турбіни допомагає розганянню (рис. 5).

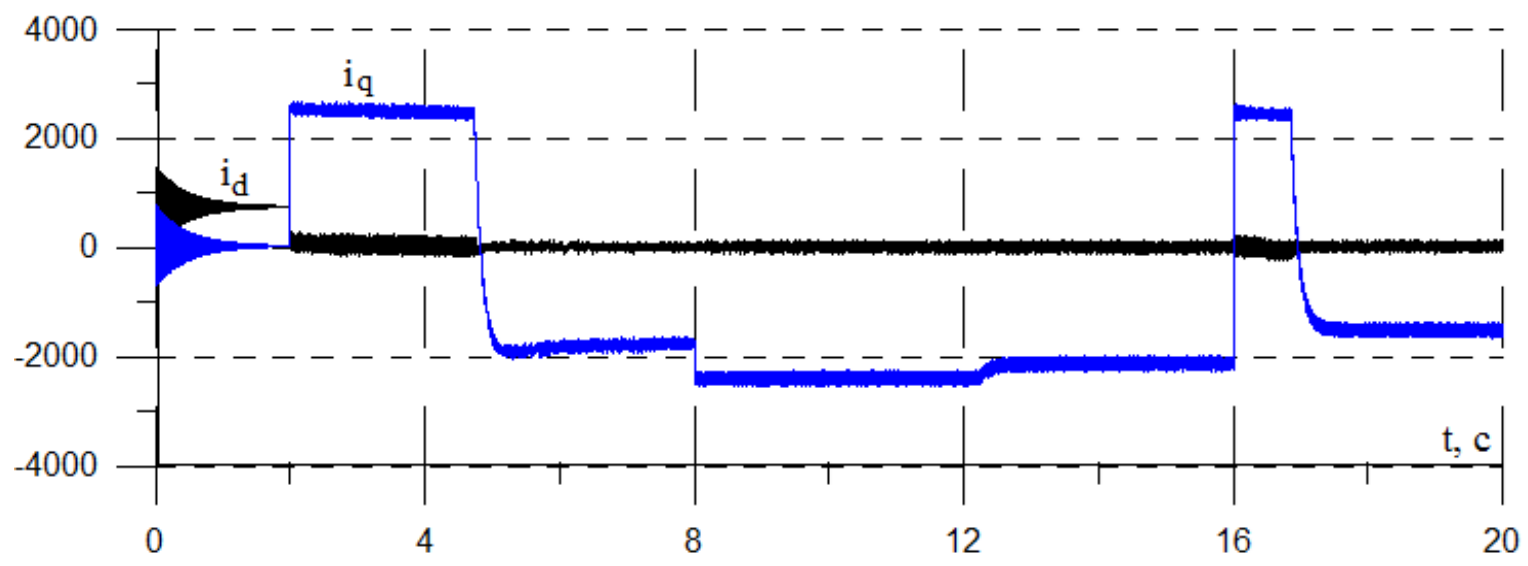

Puc. 4. Струм статора в осях $d q(A)$ 


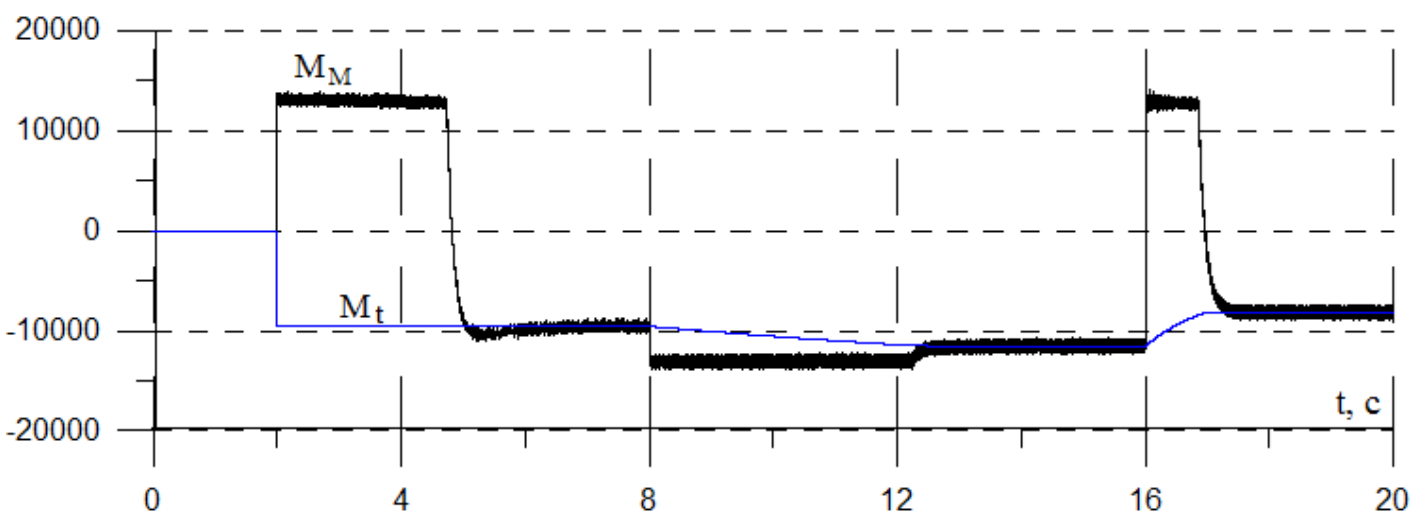

Рис. 5. Електромагнітний момент АГ (Нм), момент турбіни

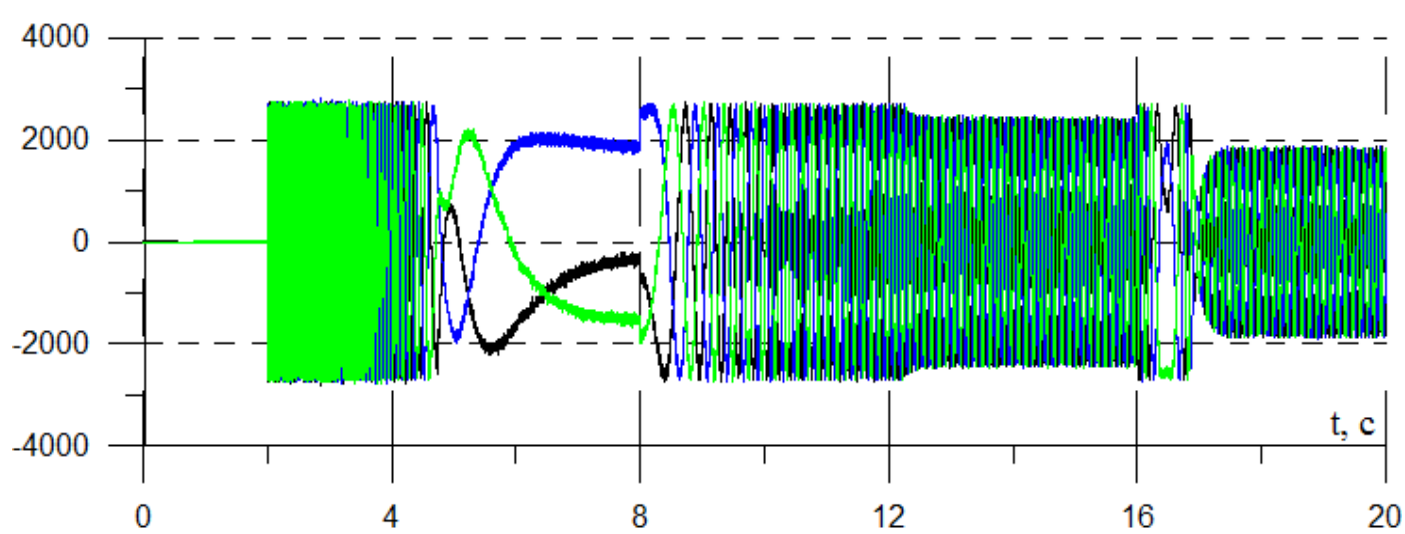

Рис. 6. Фазні струми ротора АГ (миттєві значення, А)

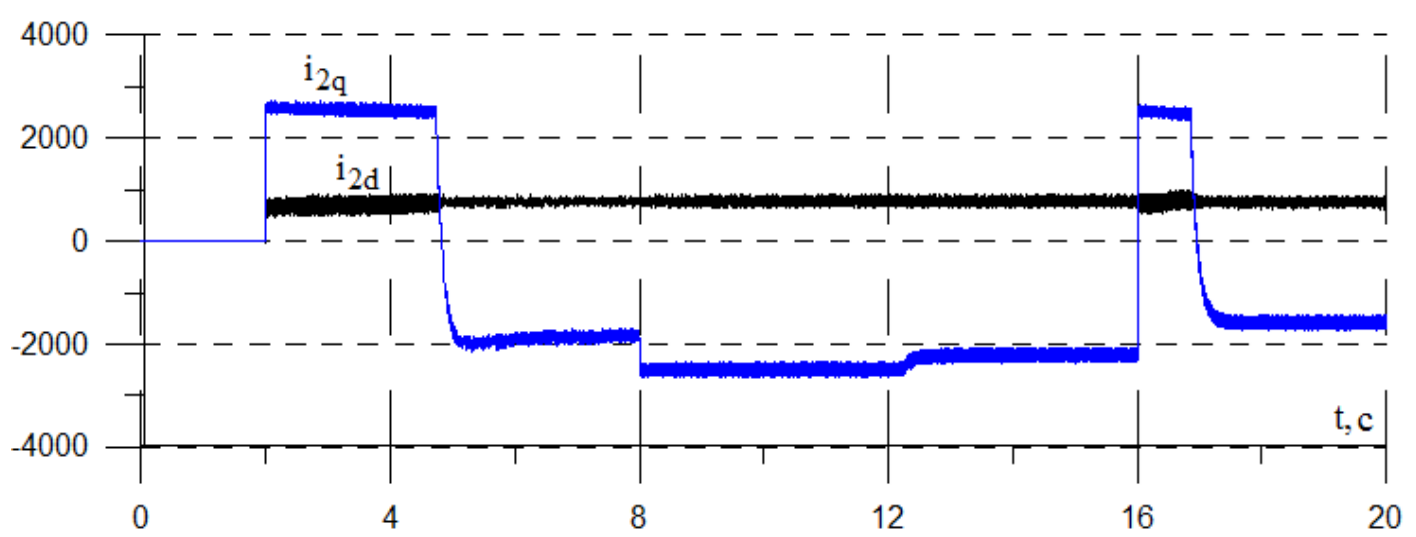

Рис. 7. Струм ротора в осях $d q$ (значення приведені до статора, А)

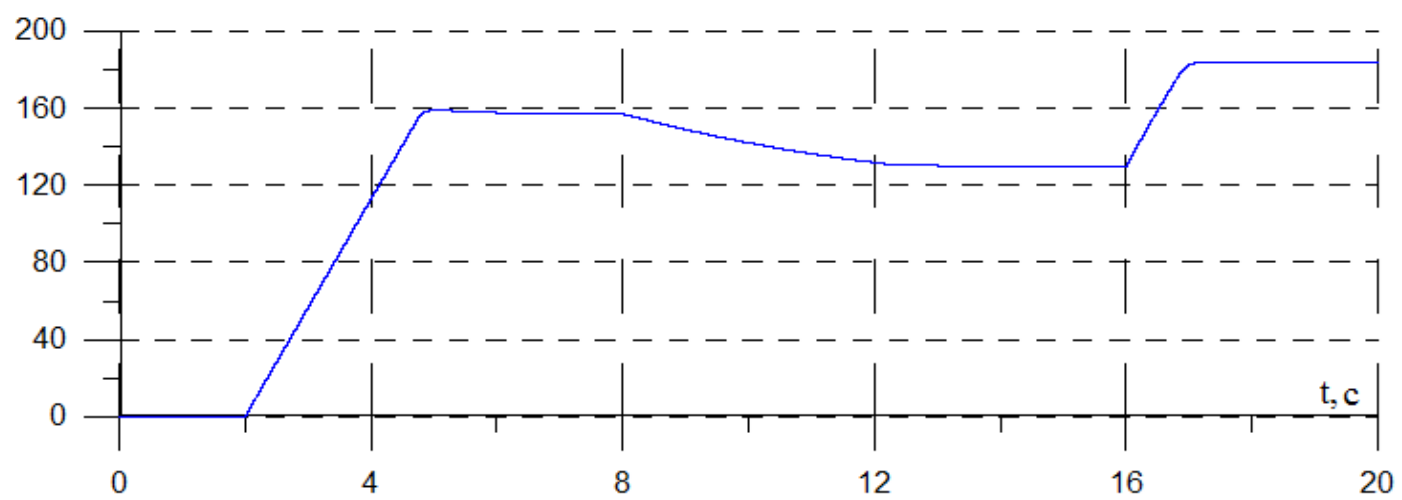

Рис. 8. Кутова швидкість обертання, $c^{-1}$ 


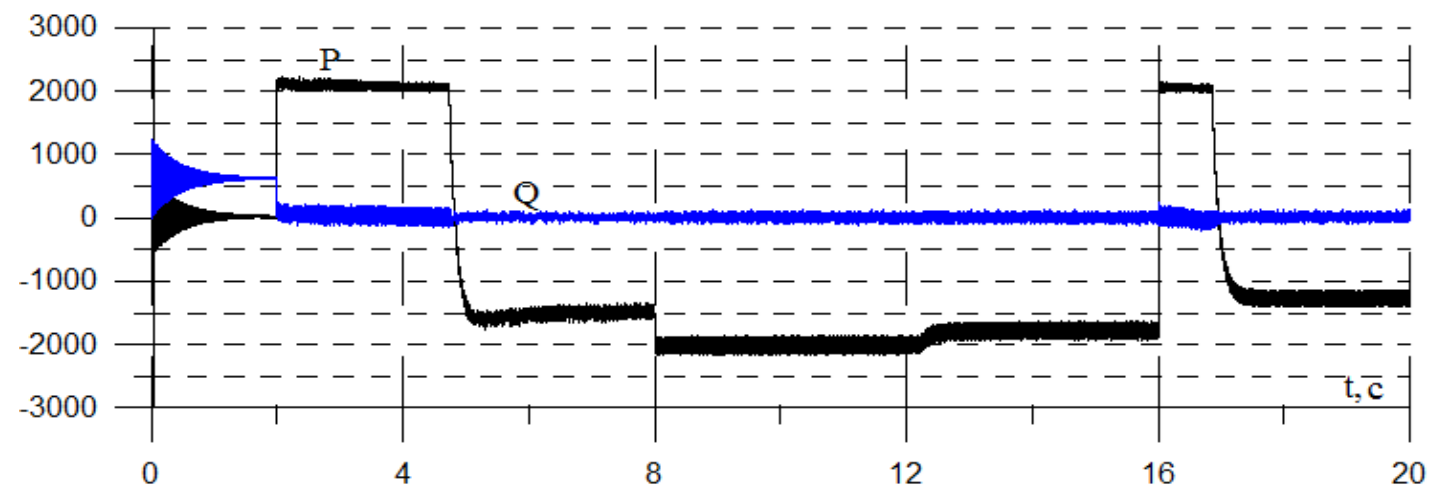

Рис. 9. Активна потужність $P_{1}$ та реактивна потужність статора (кBm, кBA)

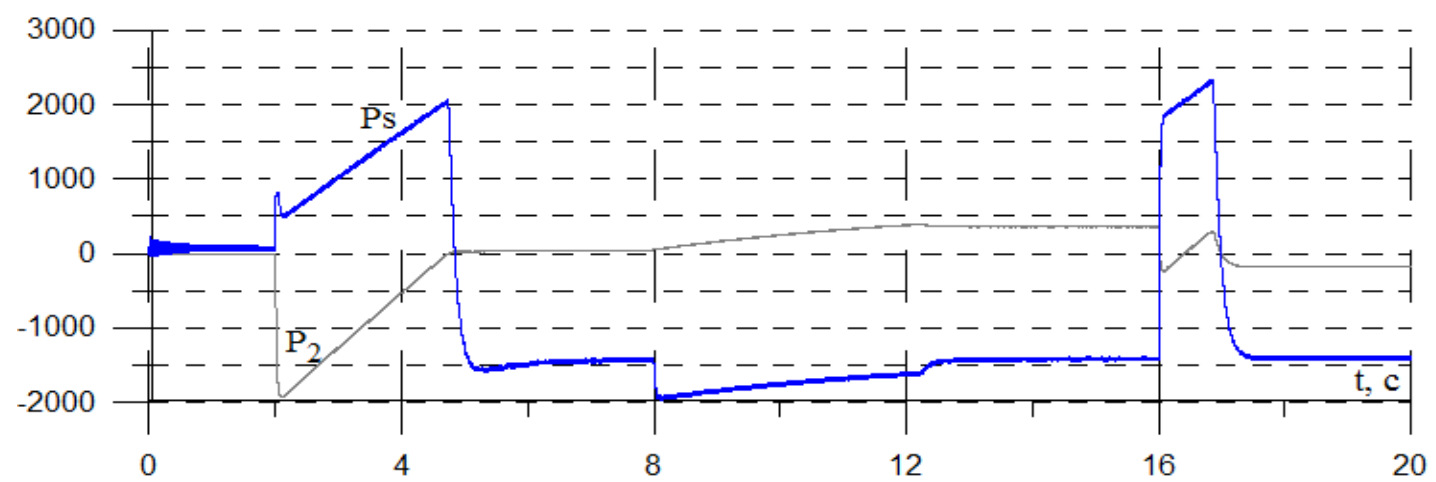

Рис. 10. Активна потужність на виході АГ $P_{s}$, активна потужність, яку споживає коло ротора $P_{2}$. Потужність на валу $1500 \kappa \mathrm{Bm}$

Як видно 3 отриманих осцилограм, струм статора асинхронного генератора по осі $d$ в усталеному режимі дорівнює 0 (рис. 4), тобто система векторного керування забезпечує роботу генератора із одиничним коефіцієнтом потужності (рис. 9). Складова струму статора по осі $q$ прямо пропорційна до електромагнітного моменту (рис. 5). Струм ротора АГ по осі $d \in$ струмом намагнічування, а складова струму ротора по осі $q$ компенсує відповідну складову струму статора (рис. 7).

3 отриманих осцилограм можна простежити баланс потужності. В нормальному режимі роботи генератор віддає активну потужність у мережу, що відповідає іiї від’ємному знаку (рис. 9). Її значення менше від потужності на валу генератора на величину втрат $\Delta P$. Значення активної потужності в роторі $P_{2}$ прямо пропорційне до ковзання. У випадку роботи зі швидкістю обертання, меншою за синхронну, ротор споживає активну потужність $\left(P_{2}>0\right)$, а у випадку роботи зі швидкістю обертання, вищою за синхронну, - віддає потужність $\left(P_{2}<0\right.$, рис. 10). В загальному випадку потужність на виході асинхронного генератора $P_{s}=P_{1}+P_{2}=P_{s}-\Delta P$, де $P_{1}$ - потужність у колі статора, $P_{6}$ - потужність на валу.

\section{Висновки}

Використання методу середніх напруг на кроці числового інтегрування дає змогу забезпечити високу швидкодію розробленої моделі та ії тривалу (десятки годин) неперервну роботу в режимі реального часу в поєднанні із фізичними об'єктами (наприклад, із фізичним контролером), що дає змогу використовувати іiі для синтезу та тестування систем керування асинхронним генератором. Отримані результати коректно відображають закономірності перетворення енергії в асинхронному генераторі та баланс потужності, що свідчить про адекватність розробленої моделі. Реалізована в моделі система векторного керування забезпечує регулювання швидкості обертання генератора та 
реактивної потужності в колі статора і створює умови для використання зазначеної системи, наприклад, для вітроенергетичних установок.

\section{Список використаних джерел}

1. Qiao W., "Dynamic modeling and control of doubly fed induction generators driven by wind turbines", 2009 IEEE/PES Power Systems Conference and Exposition, Seattle, WA, 2009, pp. 1-8.

2. Pak L-F., Dinavahi V., Real-time simulation of wind energy system based on the doubly-fed induction generator, IEEE Transactions on Power Systems, vol. 24, no. 3 (2009), 1301-1309.

3. Wang C., Fang X., Yongjie F., Comparative simulation of dynamic characteristic of wind turbine doubly-fed induction generator based on RTDS and Matlab, IEEE International Conference on Power System Technology, (2010), 1-8.

4. Wu F., Zhang X. P., Godfrey K., Ju P., Small signal stability analysis and optimal control of a wind turbine with doubly fed induction generator, IET- Generation, Transmission and Distribution, vol. 1, no. 5 (2007), 751-760.

5. Lei T., Barnes M. and Ozakturk M., "Doubly-fed induction generator wind turbine modelling for detailed electromagnetic system studies", in IET Renewable Power Generation, March 2013, vol. 7, no. 2, pp. 180-189,.

6. Ufa R. A., Vasilev A. S. and Suvorov A. A., "Development of hybrid model of B2B HVDC", 2017 International Conference on Industrial Engineering, Applications and Manufacturing (ICIEAM), St. Petersburg, 2017, pp. 1-5.

7. Ou K. et al., "MMC-HVDC Simulation and Testing Based on Real-Time Digital Simulator and Physical Control System”, in IEEE Journal of Emerging and Selected Topics in Power Electronics, Dec. 2014, vol. 2, no. 4, pp. 1109-1116.

8. Plachtyna O. A hybrid model of the electrical power generation system / O. Plachtyna, A. Kutsyk // Proceeding of 10th International Conference on Compatibility, Power Electronics and Power Engineering (CPEPOWERENG), IEEE Conference Publications, 2016, pp. 16-20.

9. Плахтина О. Г. Числовий однокроковий метод аналізу електричних кіл $i$ його застосування в задачах електромеханіки, Вісник НТУ “Харківський політехнічний інститут”, 2008, № 30, с. 223-225.

Plachtyna O. G. Chyslowyj odnokrokowyj metod anlizu elektrychnych kil i joho zastosuvannia $v$ zadachah elektromechaniky. [Numerical one-step method for the analysis of electric circuits and its application in the problems of electromechanics]. Visnyk NTU "Harkivskij politehnichnyj instytut". 2008, No. 30, pp. 223-225. (ukr.)

10. Плахтына Е. Г. Математическое моделирование электромашиновентильных систем. Львов: Вища школа, 1986. $161 \mathrm{c}$.

Plachtyna E. G. Matematicheskoje modelirovanie elektromashyno-ventilnyh sistem. [Mathematical modeling of electromechanical systems with semiconductor converters]. Lviv: Vyshcha shkola, 1986. 161 p. (rus.)

11. Плахтина О. Г., Куцик А. С., Тутка В. В. Синхронізаиія розрахункового часу функиіонування математичних моделей електромашиновентильних систем з реальним часом // Вісник Національного університету “Львівська політехніка" "Електроенергетичні та електромеханічні системи". 2009, № 637. с. 67-70.

12. Plachtyna O. G., Kutsyk A. S., Tutka V. V. Synhronizacija rozrahunkovogo chasu funkcionuvannia matematychnych modelej elektromashynoventylnyh system z realnym chasom. [Synchronization of the calculated time of electromechanical systems mathematical models with a real-time] // Visnyk Lviv Politechnic National University "Electric power and electromechanical systems". 2009, No. 637, pp. 67-70.

\section{References}

1. Qiao W., "Dynamic modeling and control of doubly fed induction generators driven by wind turbines", 2009 IEEE/PES Power Systems Conference and Exposition, Seattle, WA, 2009, pp. 1-8.

2. Pak L-F., Dinavahi V., Real-time simulation of wind energy system based on the doubly-fed induction generator, IEEE Transactions on Power Systems, vol. 24, no. 3 (2009), 1301-1309.

3. Wang C., Fang X., Yongjie F., Comparative simulation of dynamic characteristic of wind turbine doubly-fed induction generator based on RTDS and Matlab, IEEE International Conference on Power System Technology, (2010), $1-8$.

4. Wu F., Zhang X. P., Godfrey K., Ju P., Small signal stability analysis and optimal control of a wind turbine with doubly fed induction generator, IET- Generation, Transmission and Distribution, vol. 1, no. 5 (2007), 751-760.

5. Lei T., Barnes M. and Ozakturk M., "Doubly-fed induction generator wind turbine modelling for detailed electromagnetic system studies", in IET Renewable Power Generation, vol. 7, no. 2, pp. 180-189, March 2013.

6. Ufa R. A., Vasilev A. S. and Suvorov A. A., "Development of hybrid model of B2B HVDC", 2017 International Conference on Industrial Engineering, Applications and Manufacturing (ICIEAM), St. Petersburg, 2017, pp. 1-5. 
7. Ou K. et al., "MMC-HVDC Simulation and Testing Based on Real-Time Digital Simulator and Physical Control System", in IEEE Journal of Emerging and Selected Topics in Power Electronics, vol. 2, no. 4, pp. 1109-1116, Dec. 2014.

8. Plachtyna O. A hybrid model of the electrical power generation system / Plachtyna O., Kutsyk A. // Proceeding of 10th International Conference on Compatibility, Power Electronics and Power Engineering (CPE-POWERENG), IEEE Conference Publications. 2016. pp. 16-20.

9. Plachtyna O. G. Chyslowyj odnokrokowyj metod anlizu elektrychnych kil i joho zastosuvannia v zadachah elektromechaniky. [Numerical one-step method for the analysis of electric circuits and its application in the problems of electromechanics] // Visnyk NTU "Harkivskij politehnichnyj instytut". 2008. No. 30. pp. 223-225. (ukr.)

10. Plachtyna E.G. Matematicheskoje modelirovanie elektromashyno-ventilnyh sistem. [Mathematical modeling of elektromechanical systems with semiconductor converters]. Lviv: Vyshcha shkola, 1986. 161 p. (rus.)

11. Plachtyna O. G., Kutsyk A. S., Tutka V. V. Synhronizacija rozrahunkovogo chasu funkcionuvannia matematychnych modelej elektromashynoventylnyh system $\mathrm{z}$ realnym chasom. [Synchronization of the calculated time of electromechanical systems mathematical models with a real-time] // Visnyk Lviv Politechnic National University "Electric power and electromechanical systems" 2009. No. 637. pp. 67-70.

\author{
A. S. Kutsyk \\ Lviv Polytechnic National University, \\ Department of Electromechatronics and Computerized Electromechanical Systems, \\ e-mail: andrii.s.kutsyk@1pnu.ua \\ O. G. Plakhtyna \\ Lviv Polytechnic National University, \\ Department of Electromechatronics and Computerized Electromechanical Systems, \\ omelian.g.plakhtyna@lpnu.ua
}

\title{
REAL-TIME MATHEMATICAL MODELLING OF ASYNCHRONOUS GENERATOR WITH VOLTAGE INVERTER IN ROTOR CIRCUIT
}

\author{
(C) Kutsyk A. S., Plakhtyna O. G., 2019
}

The mathematical model of an electromechanical system with an asynchronous generator with rotor's current regulation by frequency converter with an autonomous voltage inverter controlled by current controllers has been described in the article.

Asynchronous generators due to their simplicity are widely used in wind power plants. The rotor currents regulation by frequency converter allows to control the speed and power factor in the stator's circle. In this case, the power of the frequency converter is determined by the range of slip variation and can be $25-30 \%$ of total power of the generator.

The synthesis of the corresponding control system requires the development of a mathematical model that should take into considertion the nonlinearity of magnetic link in the asynchronous machine and the mutual interactions between components of the system. The combination of a real control system with a real-time mathematical model of the power scheme using the "hardware-in-the-loop" technology allows to test and configure the control system.

The feature of the model is the use of author's method of an average voltage on integration step for mathematical modeling of electrical circuits. The using of this method allows the high calculation performance and stability, and, also, ensured the continuous operation of the computer model in a real time mode in combination with physical objects (as example with a physical controller). This allows it to be used to synthesize and test control systems of asynchronous generator.

The vector control system implemented in the model provides the regulation of the rotational speed of the generator and the reactive power in the stator's circle and creates conditions for the use of the specified system, for example, for wind power plants.

Key words: asynchronous generator; real-time model; mathematical modeling; vector control. 